\title{
Optineurin dysfunction in amyotrophic lateral sclerosis: why so puzzling?
}

\begin{tabular}{|c|c|}
\hline \multicolumn{2}{|c|}{$\begin{array}{l}\text { NIKOLINA PRTENJAČA }{ }^{1} \\
\text { MARIN DOMINOVIĆ }^{1} \\
\text { JOSIP PERADINOVIĆ }{ }^{1} \\
\text { ROZALIJA ŠAJN }{ }^{1} \\
\text { ANDREA MARKOVINOVIĆ }{ }^{2} \\
\text { IVANA MUNITIĆ }{ }^{1, *}\end{array}$} \\
\hline \multicolumn{2}{|c|}{$\begin{array}{l}{ }^{1} \text { Laboratory of Molecular Immunology, Department } \\
\text { of Biotechnology, University of Rijeka, Rijeka, Croatia }\end{array}$} \\
\hline \multicolumn{2}{|c|}{$\begin{array}{l}{ }^{2} \text { Department of Basic and Clinical Neuroscience, } \\
\text { Maurice Wohl Clinical Neuroscience Institute, } \\
\text { Institute of Psychiatry, Psychology and Neuroscience, } \\
\text { King's College London, London, UK }\end{array}$} \\
\hline \multicolumn{2}{|c|}{$\begin{array}{l}\text { *Correspondence: } \\
\text { Ivana Munitić } \\
\text { E-mail: ivana.munitic@biotech.uniri.hr }\end{array}$} \\
\hline $\begin{array}{l}\text { Abbrev } \\
\text { ABIN } \\
\text { ALS } \\
\text { CC } \\
\text { CYLD } \\
\text { HACE1 }\end{array}$ & $\begin{array}{l}\text { viations: } \\
\text { - A20 binding and inhibitor of NF- } \kappa \mathrm{B} \\
\text { - amyotrophic lateral sclerosis } \\
\text { - coiled-coil } \\
\text { - cylindromatosis tumor suppressor protein } \\
\text { - HECT domain and ankyrin repeat containing } \\
\text { E3 ubiquitin protein ligase } 1\end{array}$ \\
\hline $\begin{array}{l}\text { Htt } \\
\text { IFNs } \\
\text { I BB } \\
\text { IRF3 } \\
\text { LC3 }\end{array}$ & $\begin{array}{l}\text { - huntingtin } \\
\text { - interferons } \\
\text { - inhibitor of } \kappa B \\
\text { - interferon regulatory factor } 3 \\
\text { - microtubule-associated protein } 1 \mathrm{~A} / 1 \mathrm{~B} \text {-light }\end{array}$ \\
\hline LIR & $\begin{array}{l}\text { - microtubule-associated protein 1A/1B-light } \\
\text { chain 3-interacting region }\end{array}$ \\
\hline $\begin{array}{l}\text { MEF } \\
\text { NEMO } \\
\text { NF- } \kappa B\end{array}$ & $\begin{array}{l}\text { - mouse embryonic fibroblasts } \\
\text { - nuclear factor } \kappa \text { B essential modulator } \\
\text { - nuclear factor kappa-light-chain-enhancer } \\
\text { of activated B cells }\end{array}$ \\
\hline NTG & - normal tension glaucoma \\
\hline Optn & - optineurin \\
\hline & - Parkinson's disease \\
\hline RIPK1 & - receptor interacting protein kinase 1 \\
\hline S0D1 & - superoxide dismutase 1 \\
\hline TBK1 & - Tank-binding kinase 1 \\
\hline TDP-43 & - TAR DNA-binding protein 43 \\
\hline TNF & - tumor necrosis factor \\
\hline UBAN & $\begin{array}{l}\text { - ubiquitin-binding domain in ABIN proteins } \\
\text { and NEMO }\end{array}$ \\
\hline & -zinc finger domain \\
\hline \multicolumn{2}{|c|}{$\begin{array}{l}\text { Received April 01, } 2020 . \\
\text { Revised May 22, } 2020 . \\
\text { Accepted May 25, } 2020 .\end{array}$} \\
\hline
\end{tabular}

\begin{abstract}
Mutations in optineurin have been linked to amyotrophic lateral sclerosis (ALS) a decade ago, but its exact role in the neurodegenerative process is still unclear. As a lysine 63 (K63)- and methionine (M1)-linked polyubiquitin-binding protein, optineurin has been reported to act as an adaptor in inflammatory signaling pathways mediated via nuclear factor kappa-lightchain-enhancer of activated $B$ cells (NF- $\kappa B$ ) and interferon regulatory factor 3 (IRF3), as well as in membrane-associated trafficking events including autophagy, maintenance of the Golgi apparatus, and exocytosis. Other studies have demonstrated its role in other processes such as regulation of mitosis, transcription, necroptosis and apoptosis. However, many of the reported effects in cell models have been proven difficult to reproduce in optineurin animal models, demonstrating the challenges of extrapolation between model systems. Knowing that multifunctional proteins present a "nightmare" for researchers, to help navigating through this field, we address the most common controversies, open questions, and artefacts related to optineurin and its role in pathogenesis of $A L S$ and other neurodegenerative diseases.
\end{abstract}

\section{INTRODUCTION}

The optineurin protein has initially been discovered in 1998 as a 1 second adenoviral E3-14.7K-interacting protein, and was thus termed FIP-2. Since then, optineurin has been reported to participate in an unusually wide number of cellular functions including inflammatory signaling, vesicular trafficking, maintenance of the Golgi apparatus, autophagy, regulation of transcription, mitosis, apoptosis and necroptosis (reviewed in $(1,2)$ ). It takes part in these processes by interacting with a large number of proteins via its ubiquitin-binding domain, microtubule-associated protein 1A/1B-light chain 3 (LC3)-interacting region (LIR), Tank-binding kinase 1 (TBK1)-interacting domain and others, and is thus considered to be an adaptor protein. Via its coiled-coil (CC) domains it oligomerizes with self, TBK1 and perhaps other proteins. Optineurin function is regulated by posttranslational modifications, most importantly phosphorylation by TBK1, ubiquitination by HECT domain and ankyrin repeat containing E3 ubiquitin protein ligase 1 (HACE1) and deubiquitination by cylindromatosis tumor suppressor protein (CYLD) (3-6). To reflect its many functions and cellular partners, its name has been changed several times, finally settling on optineurin, for optic neuropathy inducing, because of the optineurin mutations reported in primary open angle glaucoma patients (7). Of note, optineurin mutations are found specifically in normal tension glaucoma (NTG), a subset of glaucoma that arises without an increase 
in intraocular pressure. In addition, optineurin mutations distinct from those previously found in NTG have been subsequently found in amyotrophic lateral sclerosis (ALS) and frontotemporal dementia $(8-10)$. Moreover, polymorphisms resulting in lower level of optineurin expression have been found in Paget's disease of the bone and Crohn's disease $(11,12)$. Various optineurin patient mutations were proposed to act by loss-of-function, haploinsufficiency, gain-of-function or dominant negative effects, suggesting that the regulation of cellular processes by optineurin is complex, and might differ in various cell types and/or pathogenic processes. We will address common open questions, controversies and artefacts related to optineurin in pathogenesis of neurodegeneration, mostly focusing on ALS, in which more than 40 optineurin mutations have been reported thus far $(1,2)$.

\section{"Nomen est omen"?}

Optineurin has been discovered as an interacting partner to various cellular proteins, hence its many names. It was initially characterized upon being fished out in a yeast-two-hybrid screen with an adenoviral E3-14.7Kinteracting protein as a bait (13). Next, it was pulled out from a database search for proteins homologous to nuclear factor $\kappa \mathrm{B}$ essential modulator (NEMO), and was named NEMO-related protein. It harbors $53 \%$ homology to NEMO, which is most prominent in its ubiquitinbinding C-terminus (14). In 2000, optineurin was termed transcription factor IIIA-interacting protein upon being identified as an interacting partner of transcription factor IIIA, which in eukaryotic cells activates transcription of 5S RNA (15). The name optineurin was finally adopted in 2002 when its mutations were found to cause a hereditary NTG (7). Since then, optineurin has been mapped as interacting partner of many other proteins, and its mutations and polymorphisms have shown prom- inent roles in other diseases (1). Although its current name does not accurately represent all the roles that optineurin has and/or all the diseases that its mutations or polymorphisms are associated with, it bares reference to the first disease that it was linked to.

\section{Optineurin protein-protein interactions}

Optineurin is a non-enzymatic protein that harbors several functional domains and interacts with a large number of proteins (16). It has an LC3 and TBK1 binding regions in its $\mathrm{N}$-terminus, and an ubiquitin-binding domain in the C-terminus (Figure 1). In addition, CC domains cover a large part of optineurin (around 70\%), and mediate its self-oligomerization and oligomerization to other proteins harboring CC domains. Optineurin regulates protein degradation, cell trafficking and signal transduction through binding linear lysine 63 (K63)- and methionine (M1)-linked ubiquitin. The ubiquitin-binding domain of optineurin is highly homologous to several regulators of the nuclear factor kappa-light-chainenhancer of activated B cells (NF- $\kappa$ B) pathway: a positive regulator NEMO and negative regulators A20 binding and inhibitor of NF- $\kappa \mathrm{B}$ (ABIN) proteins, and is thus named ubiquitin-binding domain in ABIN proteins and NEMO (UBAN) (17). The high specificity for linear ubiquitin is provided by the zinc finger domain (ZF), located distally to UBAN (18). Some of the ubiquitinated proteins that optineurin binds are receptor interacting protein kinase 1 (RIPK1), which controls NF- $\kappa$ B activation, and myosin VI, a motor protein important in vesicle trafficking and autophagy. During autophagy, optineurin also recognizes ubiquitinated intracellular bacteria, protein aggregates and damaged mitochondria $(3,19,20)$. To function as an autophagy receptor, optineurin bridges ubiquitinated cargo to autophagosomes via its LIR domain (3). Notably, LIR is fully functional only upon

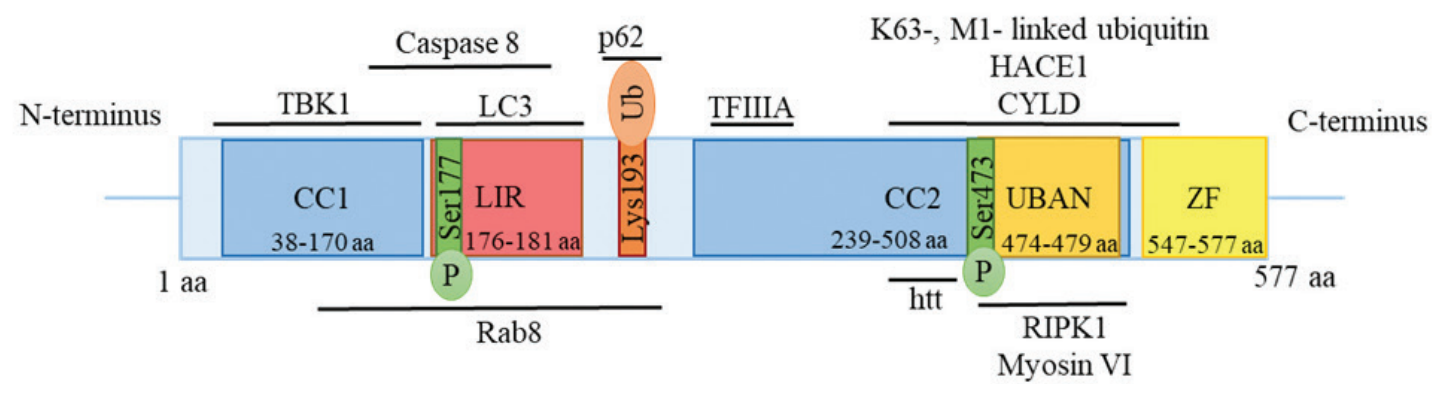

Figure 1. Schematic representation of optineurin domains and interacting partners. $N$-terminus of optineurin possesses coiled-coil domain 1 (CC1) that interacts with TBK1, LC3-interacting region (LIR) that harbors Ser177, which is phosphorylated by TBK1 to enhance binding between optineurin and LC3. Optineurin ubiquitination is mediated by an ubiquitin ligase HACE1, which ubiquitinates optineurin on Lys193. This posttranslational modification is required for p62 binding to optineurin. Coiled-coil 2 (CC2) domain is crucial for self-oligomerization of optineurin, which is important for binding to linear ubiquitin. Ubiquitin-binding domain (UBAN), important for binding polyubiquitinated cargo including intracellular bacteria, protein aggregates and damaged mitochondria, is located at the C-terminus. UBAN is also important for binding RIPK1, regulator of the NF- $\kappa B$ pathway, and myosin VI, a motor protein important in vesicle trafficking and autophagy. Zinc finger domain (ZF) maps distally to UBAN. Phosphorylation on Ser473 enhances optineurin binding to ubiquitin. Rab8 and caspase 8 bind to the N-terminus, transcription factor IIIA (TFIIIA) to the intermediate region, and CYLD deubiquitinase and huntingtin (htt) to C-terminus of optineurin. Remark: the domain sizes are not drawn to scale to accommodate their designations. 
phosphorylation of Ser177 by TBK1. The complexity of the interaction between optineurin and TBK1 is also seen in the signaling pathway necessary for IFN- $\beta$ production, whereby their stable interaction is inducible upon cell activation by pathogen associated molecular patterns. This process was reported to be bipartite: the two proteins initially associate via $\mathrm{N}$-terminal CC1 domain of optineurin and C-terminal CC2 of TBK1, and this is stabilized upon TBK1 ubiquitination, which allows its binding to optineurin UBAN domain $(4,21)$. Phosphorylation of optineurin by TBK1 may also be required for stabilization of this interaction. Similarly, self-oligomerization of optineurin via the CC2 domain, was found to be crucial for binding of linear ubiquitin (22).

The role of optineurin self-oligomerization has been debated for a long time because it could potentially lead to protein aggregation. Native gel electrophoresis suggested that endogenous optineurin forms hexamers (23). Moreover, oxidative stress has been proposed to trigger cross-linking of optineurin oligomers (24). However, optineurin ALS mutations were not detected in aggregates, suggesting that it does not act by gain-of-function i.e. toxicity. In contrast, immunohistochemical analysis of sporadic ALS cases, showed aggregation of wild-type optineurin in skein-like inclusions and round hyaline inclusions in the spinal cord, suggesting that optineurin appears to be a general marker for ALS (25). Optineurin presence in aggregates was demonstrated in several other neurodegenerative diseases including Alzheimer's, Parkinson's (PD) and Huntington's disease. The role of wildtype optineurin in these aggregates has not been conclusively clarified.

\section{Optineurin cellular localization}

Optineurin is a widely expressed cytoplasmic protein. Many studies confirmed that optineurin is prominently present in the perinuclear region around the Golgi apparatus (26). One of the proposed candidates accountable for driving this localization is huntingtin (htt), an adaptor protein preferentially located at the Golgi apparatus. $\mathrm{Mu}$ tations of htt caused by polyglutamine repeats take part in intracytoplasmic inclusions in Huntington's disease, a neurodegenerative disease characterized by involuntary movements and various cognitive and behavioral defects. In cells harboring mutated htt, optineurin binding to the htt and Golgi was reduced (27). This led to impaired recruitment of Rab8 to the Golgi apparatus, and partial blockade of the Rab8/optineurin-mediated secretion, while Rab8 was still bound to optineurin but not at the right location. Furthermore, upon activation of pathogen recognition receptors by viral sensing, optineurin was reported to serve as a recruitment platform for TBK1 activation at the Golgi apparatus (4). Prerequisite for TBK1 recognition by optineurin was TBK1 polyubiquitination on conserved lysines 30 and 401. Interestingly, this pathway is apparently hijacked by viruses because NS3 protein of the Bluetongue virus acts as a decoy for optineurin, thereby diminishing TBK1 recruitment to the Golgi apparatus and its subsequent activation and downstream signaling.

Only one optineurin patient mutation, which harbors a two base pair AG insertion changing the open reading frame (691_692insAG), localizes to the nucleus (28). ALS-linked ubiquitin-binding mutations Q398X and E478G show abnormal diffuse cytoplasmic distribution in non-vesicular manner and elicit Golgi fragmentation in motor neuron-like NSC-34 cells $(28,29)$. Wild-type optineurin also colocalizes with ubiquitinated cellular cargo destined for degradation, whereas many ubiquitinbinding mutants fail to do so (3). However, ubiquitinbinding mutants do not completely lose their ability to bind to cargo so it is possible that they partially retain their normal location by piggybacking to endogenous optineurin or some of its protein partners $(19,30)$. Some uncertainties about optineurin location remain because immunostaining patterns depend on antibodies, tags and washing procedures. For example, adding glycine in a washing step that has been used previously for antigen retrival, can result in uncovering new epitope(s) and thus different immunostaining patterns (26). Thereby, a diffuse, cytoplasmic distribution of optineurin was present when cells were washed in glycine, whereas without that step, the cytoplasmic staining was low and optineurin was located in the perinuclear area overlapping with the Golgi marker GM130. Other inconsistencies in optineurin staining in overexpression models could also be attributed to supraphysiological level of binding to ubiquitin, p62 and other targets.

\section{Optineurin as one of many amyotrophic lateral sclerosis-linked genes}

ALS, also known as Lou Gehrig's disease, is a heterogeneous neurodegenerative disease characterized by the death of motor neurons at three levels: the primary motor cortex, brainstem and spinal cord (31). In up to $50 \%$ of patients it can also affect cognition and behavior by targeting neurons in the frontal and temporal cortex (32). Loss of motor neurons leads to skeletal muscle weakness, problems in swallowing and talking, which rapidly progress to complete muscle paralysis and death, most often due to inability to breathe (31). ALS has a complex genetic background $(32,33)$. Only $10 \%$ of cases are famil$\mathrm{ial}$, although the genetic component is high even in sporadic cases. The discrepancy in the frequency of familial and genetic cases is due to de novo mutations, incomplete penetrance and misdiagnosis, among others. Despite an enormous progress in finding ALS-linked mutations, which encompass more than 30 genes so far, understanding their mechanism of action has proved to be a great challenge. One of the most prominent features of ALS is protein aggregation but its direct mechanistic link to neuronal dysfunction is debated (34). Other proposed mech- 
anisms include impaired aggregate disposal via autophagy or proteasomes, defective RNA metabolism/stress granule formation, mitochondrial dysfunction, enhanced excitotoxic death, impaired nucleocytoplasmic transport, cytoskeletal and axonal defects, impaired DNA repair, and defects in vesicle trafficking $(32,35)$. Moreover, neuronal dysfunction is accompanied by inflammatory processes and proliferation of glial cells (32). In this respect it is perhaps not surprising that the direct link to disease is unclear for optineurin mutations as well. As an adaptor in inflammatory signaling, autophagy, and exocytosis, optineurin could contribute to neurodegeneration in several of the above-mentioned pathways.

Around 40 optineurin mutations have been found in hereditary and sporadic ALS patients. The majority are point mutations, including both missense and nonsense mutations. Most of them are in ubiquitin-binding region or CC domains, suggesting that binding of ubiquitin, oligomerization, and protein-protein interactions are responsible for the disease pathogenesis (26). Because mutated optineurin was not detected in aggregates, as discussed above, it is thought that optineurin mutations give rise to the loss of its functions rather than new toxic functions (1). The first optineurin mutations with proven pathogenicity were a homozygous null mutation of exon 5, a homozygous nonsense Q398X and a heterozygous E478G missense point mutation (8). Homozygous mutations of exon 5 and a Q398X nonsense mutation that encodes for a premature stop codon suggest that disease occurs when both alleles are affected leading to loss of complete protein or its ubiquitin-binding region.

\section{Cellular and animal models for optineurin research}

Some of the initial approaches in studying protein function include protein-protein interactions in yeast or bacterial systems, often followed by overexpression studies in cellular models. All of these have been used in optineurin research. Very often the cell line studied is selected based on its ease of transfectability, availability, and not on its relevance for a particular disease. Those include HEK293 and HeLa cells, which might be problematic when analyzing potential cell-specific effects. Furthermore, various ALS or glaucoma patient mutations, as well as artificial mutations that include constitutively active variants, point mutations in relevant domains which lead to loss-of-function or dominant negative effects, have been used in optineurin overexpression studies. However, overexpressed proteins do not necessarily replicate the interactions and/or oligomerization patterns of proteins expressed at physiologic levels. In particular, because more than $70 \%$ of optineurin is predicted to form CC domains, it has a high propensity for oligomerization or self-oligomerization. Oligomerization, combined with overexpression that makes proteins supersaturated, would thus facilitate non-physiologic aggregation of optineurin (36).
Therefore, it is possible that some optineurin patient mutations that were reported to aggregate in in vitro systems do not behave the same in vivo. It must also be noted that some cellular functions are particularly difficult to study. For example, when studying autophagy, one has to be aware of a number of potential artefacts that could lead to data misinterpretation, which will be discussed later.

The first attempts to analyze optineurin function in vivo were in zebrafish. Morfolino-induced optineurin silencing in mutated superoxide dismutase $1\left(\mathrm{SOD}^{\mathrm{G}}{ }^{\mathrm{9} 3 \mathrm{~A}}\right)$ model, harboring the most researched aggregation-prone ALS patient mutation, resulted in cell death, motor axonopathy, but no motor phenotypes were noted (19). After that, several optineurin mouse models were designed to mimic the pathogenic ALS-linked mutations (Table 1). The first developed was the mouse knock-in model harboring a D477N optineurin $\left(\mathrm{Optn}^{\mathrm{D} 477 \mathrm{~N}}\right)$ point mutation, which mimics the E478G mutation found in ALS patients and lacks the ubiquitin-binding activity (37). In the same line was the optineurin truncation 1-470 $\left(\mathrm{Optn}^{470 \mathrm{~T}}\right)$, which lacks whole ubiquitin-binding domain (UBAN and ZF), and the distal part of CC2 domain, and as such perhaps best mimics Q398X truncation in humans (38). Another model, an $\mathrm{N}$-terminal deletion $\left(\mathrm{Optn} \Delta^{157}\right)$ that lacks the TBK1-binding region, was designed to study the relevance of optineurin interaction to TBK1 (21). Finally, several groups generated and/or analyzed optineurin deficiency mouse models $\left(\mathrm{Optn}^{--}\right)$, which best mimic null mutations of optineurin in ALS patients (39-41). Optineurin mouse models have shown surprisingly little functional defects, if any. One group reported axonal degeneration and defects in vertical rearing activity (40), but this was not confirmed in a follow-up study (42). Analyses of cellular functions in primary cells from optineurin animal models will be further discussed in the subsequent specialized chapters.

Given the poor overlap between optineurin models and patients, one could pose a question whether mouse models are relevant in optineurin or ALS research in general. To answer this, we would argue that the absence of an ALS-like motor phenotype in optineurin models is perhaps not surprising given that mice live on average 30 -fold shorter than humans, and do not replicate many of the age-related phenomena present in humans (43). Indeed, the optineurin deficiency and insufficiency mouse models substantially differ from classical toxic prion-like ALS models (44). For example, the first and the most used ALS transgenic model carries the human several-fold overexpressed aggregate-prone mutation $\mathrm{SOD} 1^{\mathrm{G} 93 \mathrm{~A}}$, and exhibits early motor neuron death, neuroinflammation and subsequent paralysis (45). However, all preclinical studies for ALS therapies were performed in these mice, and so far most of them failed $(44,46)$. Although attractive, this may not be an adequate model of ALS, particularly not for its sporadic form. For this reason, the emerging ALS models in other ALS-linked genes are highly sought after (44). These models will likely be valuable 
Table 1. Optineurin mouse models.

\begin{tabular}{|c|c|c|c|}
\hline $\begin{array}{l}\text { Mouse } \\
\text { model }\end{array}$ & Domain/mutation & $\begin{array}{l}\text { Related } \\
\text { human } \\
\text { mutation }\end{array}$ & Functional readouts in primary cells or in vivo \\
\hline Optn ${ }^{\mathrm{D} 477 \mathrm{~N}}$ & $\begin{array}{l}\text { Point mutation in ubiquitin-bind- } \\
\text { ing region } \\
\rightarrow \text { lacks the ubiquitin-binding } \\
\text { activity }\end{array}$ & E478G & $\begin{array}{ll}\checkmark & \text { impaired TBK1 activation, IRF3 phosphorylation and IFN- } \beta \text { production } \\
\checkmark & \text { reduced phosphorylation of OPTN } \\
\boldsymbol{x} & \text { no direct differences in NF- } \kappa \text { B activation }\end{array}$ \\
\hline Optn ${ }^{470 T}$ & $\begin{array}{l}\text { Truncation of ubiquitin-binding } \\
\text { region and the distal part of CC2 } \\
\rightarrow \text { lacks the ubiquitin-binding } \\
\text { activity; lower expression level }\end{array}$ & Q398X & $\begin{array}{ll}\checkmark & \text { impaired TBK1 activation, IRF3 phosphorylation and IFN- } \beta \text { production } \\
\checkmark & \text { disbalance in gene expression of pro- and anti-inflammatory factors } \\
\times & \text { no direct differences in NF- } \kappa \text { B activation }\end{array}$ \\
\hline Optn $\Delta^{157}$ & $\begin{array}{l}\text { N-terminal deletion } \\
\rightarrow \text { lacks TBK1-binding activity }\end{array}$ & 1 & $\begin{array}{ll}\checkmark & \text { impaired TBK1 activation, IRF3 phosphorylation and IFN- } \beta \text { production } \\
\checkmark & \text { reduced phosphorylation of Optn } \Delta^{157} \text { by TBK1 }\end{array}$ \\
\hline Optn ${ }^{-/-}$ & $\begin{array}{l}\text { Total protein deletion } \\
\rightarrow \text { complete loss-of-function }\end{array}$ & $\begin{array}{l}\text { Null } \\
\text { muta- } \\
\text { tions }\end{array}$ & $\begin{array}{ll}\checkmark & \text { impaired TBK1 activation, IRF3 phosphorylation and IFN- } \beta \text { production } \\
\checkmark & \text { mice more susceptible to Salmonella infection } \\
\checkmark & \text { increased necroptosis in oligodendrocytes and mouse embryonic fibroblasts } \\
\checkmark & \text { mildly increased proinflammatory cytokines in vivo (in unmanipulated mice) } \\
\times & \text { no direct differences in NF- } \mathrm{B} \text { activation }\end{array}$ \\
\hline
\end{tabular}

even if the impact of a particular mutation is not seen in unmanipulated mice, because they could in turn be used to analyze the cumulative effects of other ALS-predisposing factors, both environmental and genetic. This is likely particularly important for loss-of-function models, which are less likely to exhibit functional defects than transgenic (overexpression) models.

It is notable that neither animal- nor patient-inducedpluripotent stem cell models are available for most optineurin patient mutation missense mutations. For this reason, they are still analyzed only in cellular models. For example, some mutations including R96L, E478G and V295F were analyzed in functional studies by in vitro overexpression $(28,47)$. Altogether, in vivo models are considered more relevant for addressing physiologic functions of particular genes, whereas the in vitro research is valuable for initial characterizations of molecular mechanisms. However, limitation of each model must be taken into account.

\section{Inflammatory signaling}

The first reported mutations in optineurin were proposed to trigger excessive inflammatory responses, which is an attractive hypothesis for neurodegeneration (8). Indeed, ever since activated microglia and astrocytes were reported to inflict collateral damage to neighboring neurons in ALS and other neurodegenerative diseases (48, 49), it was unclear if this was exclusively an aftermath of neuronal damage or if glial cells could also be the primary trigger of neuronal death. Optineurin and several of its interacting proteins such as TBK1 and RIPK1, are key regulators of innate immune responses. Importantly, mutations in TBK1, which result in its haploinsufficiency have also been recently described in ALS patients, opening a possibility that innate immune responses could participate in ALS initiation and/or progression $(50,51)$.

\section{Optineurin in NF-KB signaling pathway}

Activation of the NF- $\kappa$ B pathway via Toll-like receptors or other pathogen or damage sensors leads to proinflammatory cytokine secretion (52). Inflammatory signaling is highly regulated to orchestrate the appropriate magnitude of response to an individual threat. Thus, various feedback loops either amplify or block signaling in immune cell subsets to avoid, on one hand, suboptimal responses incapable of clearing the damage, as well as exaggerated responses leading to autoimmunity and/or autoinflammation. Due to its high homology to NEMO, optineurin was initially proposed to block the NF- $\kappa$ B pathway by competitively binding to polyubiquitinated RIPK1 $(14,53)$. RIPK1 normally gets ubiquitinated upon pathogen or damage sensing, which allows docking of $\mathrm{NEMO}$, a regulatory component of the $\mathrm{I} \kappa \mathrm{B}$ kinase complex. I $\kappa \mathrm{B}$ kinase complex then gets activated and phosphorylates the inhibitor of $\kappa \mathrm{B}(\mathrm{I} \kappa \mathrm{B})$, which leads to its degradation and allows NF- $\kappa$ B translocation to the nucleus, thus triggering the secretion of proinflammatory cytokines such as interleukin $1 \beta$ and tumor necrosis factor (TNF). For these reasons, the possibility that hyperactivation of the NF- $\kappa$ B could trigger neurodegeneration was studied as a potential mechanism of action of optineurin mutations.

In vitro studies showed that overexpressed optineurin inhibited NF- $\kappa \mathrm{B}$ activation by competing with NEMO in HEK293 cells (53). Conversely, overexpression of patient ALS mutation E478G, which is deficient in ubiquitin binding, was incapable of NF- $\kappa$ B inhibition in NSC-34 and neuroblastoma Neuro2A mouse cell lines $(8,54)$. Unlike these results in cell lines though, the investigations in primary murine cells from several models of optineurin deficiency and insufficiency $\left(\mathrm{Optn}^{470 \mathrm{~T}}, \mathrm{Optn}^{\mathrm{D} 477 \mathrm{~N}}\right.$ and $\mathrm{Optn}^{\Delta 157}$ ), showed no influence of optineurin on the acti- 
vation of NF- $\kappa \mathrm{B}$ pathway and subsequent TNF production in various primary cells including macrophages, dendritic cells, mouse embryonic fibroblasts (MEFs), and osteoclasts $(4,21,38,39)$. Optineurin was also dispensable for TNF production in neonatal microglia (16). Since optineurin is upregulated by the NF- $\kappa \mathrm{B}$ pathway itself (55), it was also tested if it was a late regulator of this pathway, but the analyses done in macrophages and microglia were negative as well $(16,38)$. All of these reports strongly suggested that the initial characterization of optineurin function in cell lines by overexpression and silencing was an artefact of the experimental system, perhaps due to non-specific binding and transfection artefacts. However, a recent study suggested that ALS mutation E478G led to enhanced NF- $\kappa$ B activation and nuclear translocation in $\mathrm{Optn}^{-/} \mathrm{MEFs}$ (56). When the same mutation was delivered to mouse motor cortex via a lentiviral vector, it led to neuronal death, accompanied with microglia and astrocyte activation. Similarly, a minor increase in expression of inflammatory genes was reported in an optineurin deficiency model, although this was reported to be secondary to increased necroptosis (40). Therefore, because of these contradictory data, the role of optineurin in the NF- $\kappa$ B pathway is still unclear. Several possibilities could explain for these discrepancies. Firstly, given the potential distinct cell-specific effects, it is possible that optineurin regulates this pathway only in selected cell subsets. Therefore, the effects of optineurin mutations should be tested in a broad panel of cell model systems. Secondly, it is possible that the stimuli used on the primary cells do not represent the dangers faced by neurons or glia in the CNS. For this reason, it would be necessary to use the agents proven to elicit neurotoxicity and/or study neuron:glia co-cultures or otherwise mimic the CNS microenvironment. Thirdly, optineurin could have distinct effects in mouse and human cells. Finally, although it was initially presumed that optineurin deficiency and putative loss-of-function mutations have the same effects, this might not be the case. It is possible that point mutations or truncations act as dominant-negative and/or toxic gainof-function mutations. Therefore, to understand if indeed optineurin regulates the NF- $\kappa \mathrm{B}$ pathway, it will be crucial to study these possibilities.

\section{Optineurin in interferon regulatory factor 3 signaling pathway}

Type I interferons (IFNs), including IFN- $\beta$ that is expressed in all cells, are essential for elimination of viruses and certain bacteria $(57,58)$. Their production is regulated by the transcription factor IRF3, which is activated downstream of the same pathogen or damage sensors that trigger NF- $\kappa$ B activation. Activation of IRF3 is mediated by TBK1, which activates IRF3 by phosphorylation. After Toll-like receptor activation, optineurin interacts with TBK1 at the Golgi apparatus, which allows autophosphorylation of TBK1. It was initially reported that optineurin is a negative regulator of IFN- $\beta$ expression induced by Sendai virus and dsRNA in HEK293 cells (59), but various studies in primary cells from optineurin loss-of-function mouse models have shown the opposite result in response to various viral and pathogen-mimicking agents like lipopolysaccharide and polyinosinic:polycytidylic acid. For example, in primary cells including embryonic fibroblasts and various innate immune cells (macrophages, dendritic cells, microglia, osteoclasts and NK cells) optineurin deficiency or mutations compromising its ubiquitin-binding function resulted in impaired TBK1 activation and subsequent IFN- $\beta$ production (4, 16, 21, 37-39). Notably, diminished IFN- $\beta$ signaling in microglia led to a disbalance in gene expression of several pro- and anti-inflammatory factors, including IRF7, NOS2, CXCL10, CXCL1, and IL-10 (16). Therefore, the discrepancy exists in cell lines and primary cells, similar to the results in the NF- $\kappa$ B pathway. Notably, the in vivo relevance of the TBK1 pathway still needs to be assessed before final conclusions are made. IFN- $\beta$ has not thus far been linked to ALS, IFN- $\beta$ has not thus far been linked to ALS, and if confirmed, it would be a new pathogenic mechanism in ALS.

\section{Necroptosis}

Necroptosis is a caspase-independent form of programmed cell death, which results in the release of cellular components and triggers inflammation (60). ALS mouse models and patient autopsies exhibit various necroptosis markers in the affected tissues $(40,42)$. Ito $e t$ al. showed that necroptosis markers, RIPK1, RIPK3 and phosphorylated mixed lineage kinase domain-like pseudokinase (p-MLKL) were upregulated in $\mathrm{Optn}^{-1-}$ MEFs and oligodendrocytes treated with TNF (40). They have also reported upregulation of necroptosis markers in the spinal cord of SOD1 ${ }^{\mathrm{G} 93 \mathrm{~A}}$ mice and experimental RIPK3 deletion resulted in reduction of these markers (40). Necroptosis blockade in Optn ${ }^{-1}$ mice restored axonal myelinization, suggesting that necroptosis is directly linked to axonal degeneration. However, the follow-up study done by Deremntazki et al., showed equal myelinization in $\mathrm{Optn}^{-1-}$ and WT mice. Moreover, RIPK3 and p-MLKL were not upregulated in the spinal cords of SOD $1^{\mathrm{G} 93 \mathrm{~A}}$ mice, and RIPK3 deletion did not result in reduction of necroptosis markers. These results argue that necroptosis is an unlikely mechanism for optineurin mutations in ALS (42).

\section{Optineurin in membrane-associated trafficking events}

Due to the post-mitotic nature of neurons, these cells are vulnerable to increased accumulation of cellular waste and/or impaired vesicle trafficking (61). Failure of these processes demonstrably leads to neurodegeneration. Macroautophagy (hereafter referred as autophagy) is a highly conserved cellular process in charge of eliminating aggregated proteins, damaged organelles, and invading pathogens via lysosomes (62). The fact that mutations in 
optineurin and several optineurin-binding partners implicated in autophagy (TBK1, p62) were found in ALS patients, allows for the possibility that they act by disrupting autophagy during the neurodegenerative process. For example, in a SOD1 $1^{\mathrm{H} 46 \mathrm{R}}$ mouse model it was shown that loss of p62, a member of a group of autophagy receptor proteins, could worsen the disease, while p62 overexpression ameliorated the phenotype $(63,64)$. Additionally, TBK1 recruitment to optineurin was prevented by its ALS-linked E696K mutation (65, 66).

Neurodegeneration is also often characterized by Golgi fragmentation, which may not only be the consequence of the neurodegenerative process, but could also be its trigger $(67,68)$. Golgi apparatus is an organelle that processes proteins destined for secretion. It is fragmented in up to $50 \%$ of motor neurons of sporadic ALS patients (69, 70). Golgi fragmentation in SOD1 $1^{\mathrm{G} 93 \mathrm{~A}}$ model precedes neuromuscular denervation, axon retraction and inclusion formation (70). Additionally, impaired endoplasmic reticulum homeostasis is present in several neurodegenerative diseases (71). In SOD1 ${ }^{\mathrm{G} 93 \mathrm{~A}}$ mouse model of ALS for instance, depletion of Reticulon 4, an ER sculpting protein, accelerates the disease onset and progression (72). So, it is possible that optineurin mutations trigger neurodegeneration by perturbing autophagy and/or protein trafficking. Notably, some optineurin mutations found in glaucoma patients have also been reported to impact autophagy and vesicle trafficking (73-76). Because of their distinct mode of action, which includes autophagy-mediated cell death that was not reported with optineurin ALS mutations, they will not be discussed here, and the readers are referred to several recent reviews $(2,77)$.

\section{Optineurin: a pan-autophagy adaptor?}

Autophagy is a cellular process that removes aggregated proteins, damaged organelles, and invading pathogens via lysosomes (62). Autophagy can be induced by various stresses such as starvation, cytokines and potentially toxic cargo $(78,79)$. It also occurs constitutively without any additional stimuli, providing an important quality control mechanism. Constitutive (also known as basal) autophagy is particularly important in neurons, because they cannot be replaced nor divide to dilute cellular waste (80-82). Of note, neurons also cannot induce autophagy upon starvation, and have limited capacity to increase autophagy upon neurotoxic stress. Upon induction of autophagy, the toxic cargo is ubiquitinated and transported in specialized vesicles called autophagosomes. Autophagosome then fuses with lysosome to form autophagolysosome where degradation of cargo takes place (83). The transportation of ubiquitinated cargo to autophagosomes is mediated by a group of autophagy receptor proteins (alternatively referred to as adaptors), which also comprise optineurin (1).

Optineurin has initially been described as an autophagy receptor that bridges the ubiquitinated intracellular bacteria to LC3 on autophagosomal membranes (3). Numerous follow-up reports showed that optineurin binds to ubiquitinated mitochondria destined for degradation as well $(19,20,65,84)$. Damaged mitochondria become autophagy cargo upon their ubiquitination by parkin, which is activated by PTEN-induced putative kinase 1 . Redundancy with other autophagy receptors, NDP52 and TRAF6-binding protein, was reported for some but not all systems. For example, in the absence of NDP52, optineurin was dispensable for autophagy of mitochondria (mitophagy), but was indispensable for autophagy of bacteria (xenophagy). To enhance its binding to both LC3 and the ubiquitinated cargo, optineurin must be phosphorylated by TBK1 on Ser177 and Ser473 (3, 66). The follow-up research has suggested that in addition to its role in cargo selection, optineurin is implicated in two other distinct stages of autophagy: initiation and maturation. The evidence for its role in autophagy initiation comes from selective mitophagy, whereby optineurin and NDP52 are both recruited to damaged mitochondria via their ubiquitin-binding domains, and participate in recruitment of several autophagy initiating factors including Unc-51 like autophagy activating kinase 1 (20). The role of optineurin in autophagosome maturation was proposed when it was observed that it is required for autophagosomal fusion with lysosome, which is a prerequisite for subsequent fusion with endosomes (85). Optineurin does so by binding to myosin VI, which in turn binds to Tom1-positive endosomes. In addition to optineurin, two other autophagy receptors, NDP52 and TRAF6binding protein, facilitate the maturation process. It is of note that almost all of these initial reports on the role of optineurin in xenophagy and mitophagy were performed in HeLa cells, necessitating the use of more appropriate models for addressing the role of optineurin in neurodegeneration.

Several cellular models of neurodegenerative disease were used to analyze the role of optineurin in mitophagy and autophagy of abnormal protein aggregates (aggrephagy). Investigation in HeLa cells showed that depletion of optineurin or expression of ALS-associated E478G and Q398X mutations impair parkin-mediated mitophagy by inhibiting LC3 recruitment to damaged mitochondria (20, 86). Optineurin was also shown to act as a cargo receptor in aggrephagy of abnormal protein aggregates like mutated forms of SOD1, htt or TAR DNA-binding protein 43 (TDP-43) $(19,30)$. However, unlike in mitophagy and xenophagy, a study by Korac et al. (19) proposed that optineurin does not need its ubiquitin-binding domain to bind to aggregates. This discrepancy is possibly due to the usage of different experimental models and/or possible formation of optineurin wild-type/mutant dimers in an overexpression system. Several reports also demonstrated that optineurin is necessary for autophagy maturation, as mentioned above. This was further analyzed with ALS patient optineurin mutations. Optineurin mutations E478G and 
Q398X disrupted autophagosome formation and degradation of damaged mitochondria in NSC-34 cell line because of their inability to bind to myosin VI (29).

Unfortunately, there are only few reports on the role of optineurin in autophagy in primary cells, and none thus far in cells from optineurin mouse models. The importance of optineurin for the autophagy of protein aggregates characteristic for $\mathrm{PD}$ was suggested in wild-type neurons of rat rotenone model of $\mathrm{PD}$, whereby optineurin colocalized with LC3 and $\alpha$-synuclein aggregates in the dopaminergic neurons prior and during the manifestation of neurodegeneration (87). In primary mouse microglia, amyloid beta forms complexes with both optineurin and LC3, which could additionally support the role of optineurin in autophagic degradation of neurodegenerative protein aggregates (88). Recent investigation in primary neurons under mild oxidative stress confirmed some of the observations from the cell lines (89). In primary neurons, optineurin colocalized with damaged mitochondria, parkin, and LC3. The transfection of mutant E478G optineurin to wild-type cells led to mitochondrial damage, as assessed by lowered mitochondrial potential and mitochondrial swelling. However, in contrast to HeLa cells, primary neurons needed much more time for the damaged mitochondria to be delivered to the lysosome, demonstrating some discrepancies to the in vitro studies. This is the only report in which optineurin-mediated mitophagy was assessed in primary cells. It is still not clear how optineurin affects other types of autophagy and other autophagy steps in these circumstances.

To conclude, is still not clear if and/or how ALS patient optineurin mutations affect autophagy and if this is relevant to disease pathogenesis. Normally, each autophagy step is tightly regulated, so it would be unusual that optineurin serves as a potential pan-autophagy adaptor throughout this process. It is thus possible that some of the reports with overexpressed patient mutations are experimental artefacts and irrelevant for disease pathogenesis. Alternatively, it is possible that differential expression of autophagy receptors in individual cell subsets accounts for the variability in functional readouts in different systems. If so, it is conceivable that optineurin is rate-limiting for different autophagy steps in different cells. Finally, several general artefacts linked to autophagy investigation could potentially account for data misinterpretation. For example, in patient autopsy samples, autophagy is often evaluated by electron microscopy for the presence of autophagosomes, and by immunohistochemistry, immunofluorescence or immunoblotting for potential accumulation of LC3-II or autophagy receptors/substrates. However, the accumulation of LC3-II or autophagy substrates can mean either an increase in autophagy or a block in autophagosomal degradation. To distinguish between these outcomes, several inhibitors of lysosomal degradation can be used, which is difficult to achieve in mouse models and impossible in patients, thus making the autophagy detection in vivo inevitably imprecise.

\section{The role of optineurin in other trafficking events}

By binding to myosin VI, a crucial molecule for vesicle trafficking, optineurin was proposed to regulate autophagosomal maturation and maintain normal autophagic flux (85). Additionally, it was demonstrated that in NSC-34 cell line, ALS-linked optineurin mutations E478G and Q398X failed to bind to myosin VI, resulting in Golgi fragmentation and blocking the transport of secretory proteins to plasma membrane (29). A year earlier, van Dis et al. (2014) found that Golgi fragmentation in SOD $1^{\mathrm{G} 93 \mathrm{~A}}$ model neuromuscular denervation, axon retraction and inclusion formation (70). However, contrasting the in vitro findings and SOD1 overexpressing models, no obvious perturbations of Golgi structure were detected in macrophages of the mice lacking either $\mathrm{C}$ - or $\mathrm{N}$-terminus of optineurin $\left(\mathrm{Optn}{ }^{470 \mathrm{~T}}\right.$ and Optn ${ }^{\mathrm{D} 157}$ mice) $(21,38)$. This could suggest an existence of artefacts in in vitro models of vesicle trafficking. Therefore, it is still not possible to estimate impact of optineurin mutations on Golgi fragmentation in vivo. To clarify this, it will be important to conduct investigations on relevant animal models and determine whether other ALS-linked optineurin mutations have an impact on ER and Golgi apparatus in various $\mathrm{CNS}$ cell subtypes.

\section{CONCLUSIONS}

Optineurin is a multifunctional protein involved in various processes including signal transduction, cytokine secretion, vesicle trafficking and autophagy. Many of these processes overlap with the proposed ALS pathogenic mechanisms (Figure 2). Although a decade has passed since its mutations were found to cause ALS, their exact pathogenic mechanism is still elusive. Most mutations map to the $\mathrm{C}$-terminal ubiquitin-binding or CC domains suggesting that defective binding to ubiquitin or oligomerization are responsible for disease pathogenesis. Based on patient and various in vitro data in cell lines carrying overexpressed patient mutations or optineurin silencing, one could have expected overt neurological symptoms and various functional defects in optineurin mouse models. However, none of the optineurin deficiency or insufficiency mouse models spontaneously develop ALS. Moreover, investigations on inflammatory signaling, vesicle trafficking and autophagy, have shown some conflicting results in optineurin mouse models compared to the in vitro cell lines and patient data. Each of these approaches comes with its own set of potential artefacts. Overexpression studies are particularly problematic because of potential non-physiologic protein-protein interactions and protein aggregation. On the other hand, mouse models, especially those of carrying loss-of-function mutations may not develop symptoms of neurodegeneration because their life span is shorter and other evolutionary differences exist. Alternatively, substantial 


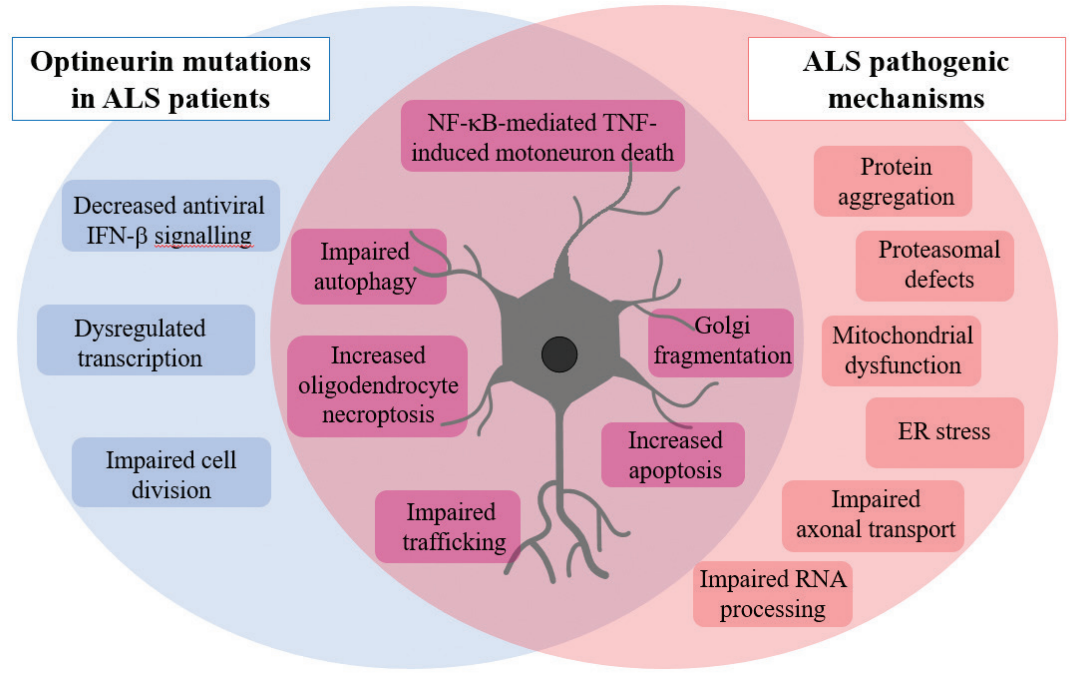

Figure 2. The effects of optineurin patient mutations overlap with ALS pathogenic mechanisms. Loss of optineurin function has been proposed to result in decreased IFN- $\beta$ signaling, dysregulated transcription of $5 S$ ribosomal RNA, defects in cell division, overactivation of $N F-\kappa B$ signaling and TNF production, blockade of autophagy, increased apoptosis and necroptosis, Golgi fragmentation and disruption in vesicle trafficking. Notably, disruption in six of these cellular processes overlap with the proposed ALS pathogenic mechanisms (marked in the overlapped area), which can also be provoked by mutations in other ALS-linked genes such as C9orf72, SOD1 and TDP-43 (35). Other molecular mechanisms that contribute to ALS pathogenesis, but so far have not been linked to optineurin are listed in the red circle.

redundancy of cellular adaptors in both autophagy and inflammation, could compensate a loss-of-function of individual genes in individual cell types or even in wholebody mouse models. In this case exacerbation of disease phenotype could be expected only under some stressful conditions and/or in the presence of additional mutations. It is also possible that different mutations cause ALS by distinct mechanisms, which could account for the variability in studies with distinct patient mutations. Therefore, future studies should focus on stressful conditions such as danger stimuli or additive mutations, which better mimic the disease pathogenesis. Other desired approaches include optineurin ALS patient derived induced pluripotent stem cells and CRISPR/Cas9-mediated introduction of patient mutations in cells or animal models.

Acknowledgments: The authors wish to thank Valentina Stimac for critical discussions. This work was supported by the Croatian Science Foundation (IP-2018-01-8563) and University of Rijeka grants (18-211-1369) to IM. The Department of Biotechnology was equipped by European Regional Development Fund (ERDF) within the project "Research Infrastructure for Campus-based Laboratories at University of Rijeka".

\section{REFERENCES}

1. MARKOVINOVICA, CIMBRO R, LJUTIC T, KRIZJ, ROGELJ B, MUNITIC I 2017 Optineurin in amyotrophic lateral sclerosis: Multifunctional adaptor protein at the crossroads of different neuroprotective mechanisms. Prog Neurobiol 154:1-20. https://doi.org/ 10.1016/j.pneurobio.2017.04.005
2. TOTH RP, ATKIN JD 2018 Dysfunction of optineurin in amyotrophic lateral sclerosis and glaucoma. Front Immunol 9:1017. https://doi.org/10.3389/fimmu.2018.01017

3. WILD P, FARHAN H, MCEWAN DG, WAGNER S, ROGOV VV, BRADY NR, RICHTER B, KORAC J, WAIDMANN O, CHOUDHARY C, DÖTSCH V, BUMANN D, DIKIC I 2011 Phosphorylation of the autophagy receptor optineurin restricts Salmonella growth. Science 333(6039): 228-233. https://doi.org/ 10.1126/science. 1205405

4. POURCELOT M, ZEMIRLIN, SILVA DA COSTA L, LOYANT R, GARCIN D, VITOUR D, MUNITIC I, VAZQUEZ A, ARNOULT D 2016 The Golgi apparatus acts as a platform for TBK1 activation after viral RNA sensing. BMC Biol 1469. https://doi.org/ 10.1186/s12915-016-0292-z

5. LIU Z, CHEN P, GAO H, GU Y, YANG J, PENG H, XU X, WANG H, YANG M, LIU X, FAN L, CHEN S, ZHOU J, SUN Y, RUAN K, CHENG S, KOMATSU M, WHITE E, LI L, JI H, FINLEY D, HU R 2014 Ubiquitylation of autophagy receptor optineurin by HACE1 activates selective autophagy for tumor suppression. Cancer Cell 26(1): 106-120. https://doi.org/10.1016/j. ccr.2014.05.015

6. NAGABHUSHANA A, BANSAL M, SWARUP G 2011 Optineurin is required for CYLD-dependent inhibition of TNF $\alpha$-induced NF- $\kappa$ B activation. PLoS One 6(3): e17477. https://doi.org/10.1371/ journal.pone.0017477

7. REZAIE T, CHILD A, HITCHINGS R, BRICE G, MILLER L, COCA-PRADOS M, HEON E, KRUPIN T, RITCH R, KREUTZER D, CRICK RP, SARFARAZI M 2002 Adult-onset primary open-angle glaucoma caused by mutations in optineurin. Science 295(5557): 1077-1079. https://doi.org/10.1126/science.1066901

8. MARUYAMA H, MORINO H, ITO H, IZUMI Y, KATO H, WATANABE Y, KINOSHITA Y, KAMADA M, NODERA H, SUZUKI H, KOMURE O, MATSUURA S, KOBATAKE K, MORIMOTO N, ABE K, SUZUKI N, AOKI M, KAWATA A, HIRAI T, KATO T, OGASAWARA K, HIRANO A, TAKUMI T, KUSAKA H, HAGIWARA K, KAJI R, KAWAKAMI H 2010 
Mutations of optineurin in amyotrophic lateral sclerosis. Nature 465(7295): 223-226. https://doi.org/10.1038/nature08971

9. POTTIER C, BIENIEK KF, FINCH N, VAN DE VORST M, BAKER M, PERKERSEN R, BROWN P, RAVENSCROFT T, VAN BLITTERSWIJK M, NICHOLSON AM, DETURE M, KNOPMAN DS, JOSEPHS KA, PARISI JE, PETERSEN RC, BOYLAN KB, BOEVE BF, GRAFF-RADFORD NR, VELTMAN JA, GILISSEN C, MURRAY ME, DICKSON DW, RADEMAKERS R 2015 Whole-genome sequencing reveals important role for TBK1 and OPTN mutations in frontotemporal lobar degeneration without motor neuron disease. Acta Neuropathol 130(1): 7792. https://doi.org/10.1007/s00401-015-1436-x

10. POTTIER C, RAMPERSAUD E, BAKER M, WU G, WUU J, MCCAULEY JL, ZUCHNER S, SCHULE R, BERMUDEZ C, HUSSAIN S, COOLEY A, WALLACE M, ZHANG J, TAYLOR JP, BENATAR M, RADEMAKERS R 2018 Identification of compound heterozygous variants in OPTN in an ALS-FTD patient from the CReATe consortium: a case report. Amyotroph Lateral Scler Frontotemporal Degener 19(5-6): 469-471. https://doi.org/ 10.1080/21678421.2018.1452947

11. ALBAGHA OM, VISCONTI MR, ALONSO N, LANGSTON AL, CUNDY T, DARGIE R, DUNLOP MG, FRASER WD, HOOPER MJ, ISAIA G, NICHOLSON GC, DEL PINO MONTES J, GONZALEZ-SARMIENTO R, DISTEFANO M, TENESA A, WALSH JP, RALSTON SH 2010 Genome-wide association study identifies variants at CSF1, OPTN and TNFRSF11A as genetic risk factors for Paget's disease of bone. Nat Genet 42(6): 520 524. https://doi.org/10.1038/ng.562

12. SMITH AM, SEWELL GW, LEVINE AP, CHEW TS, DUNNE J, O'SHEA NR, SMITH PJ, HARRISON PJ, MACDONALD CM, BLOOM SL, SEGAL AW 2015 Disruption of macrophage pro-inflammatory cytokine release in Crohn's disease is associated with reduced optineurin expression in a subset of patients. Immunology 144(1): 45-55. https://doi.org/10.1111/imm.12338

13. LI Y, KANG J, HORWITZ MS 1998 Interaction of an adenovirus E3 14.7-kilodalton protein with a novel tumor necrosis factor alphainducible cellular protein containing leucine zipper domains. Mol Cell Biol 18(3): 1601-1610. https://doi.org/10.1128/mcb.18.3.1601

14. SCHWAMBORN K, WEIL R, COURTOIS G, WHITESIDE ST, ISRAEL A 2000 Phorbol esters and cytokines regulate the expression of the NEMO-related protein, a molecule involved in a NF-kappa B-independent pathway. J Biol Chem 275(30): 22780-22789. https://doi.org/10.1074/jbc.M001500200

15. MORELAND RJ, DRESSER ME, RODGERS JS, ROE BA, CONAWAY JW, CONAWAY RC, HANAS JS 2000 Identification of a transcription factor IIIA-interacting protein. Nucleic Acids Res 28(9): 1986-1993. https://doi.org/10.1093/nar/28.9.1986

16. MARKOVINOVIC A, LJUTIC T, BELAND LC, MUNITIC I 2018 Optineurin insufficiency disbalances proinflammatory and anti-inflammatory factors by reducing microglial IFN-beta responses. Neuroscience 388139-151. https://doi.org/10.1016/j.neuroscience.2018.07.007

17. WAGNER S, CARPENTIER I, ROGOV V, KREIKE M, IKEDA F, LOHR F, WU CJ, ASHWELL JD, DOTSCH V, DIKIC I, BEYAERT R 2008 Ubiquitin binding mediates the NF-kappaB inhibitory potential of ABIN proteins. Oncogene 27(26): 3739-3745. https://doi.org/10.1038/sj.onc.1211042

18. LAPLANTINE E, FONTAN E, CHIARAVALLI J, LOPEZ T, LAKISIC G, VÉRON M, AGOU F, ISRAËL A 2009 NEMO specifically recognizes K63-linked poly-ubiquitin chains through a new bipartite ubiquitin-binding domain. EMBO J 28(19): 2885-2895. https://doi.org/10.1038/emboj.2009.241

19. KORAC J, SCHAEFFER V, KOVACEVIC I, CLEMENT AM, JUNGBLUT B, BEHL C, TERZIC J, DIKIC I 2013 Ubiquitinindependent function of optineurin in autophagic clearance of protein aggregates. J Cell Sci 126(Pt 2): 580-592. https://doi.org/ $10.1242 /$ jcs. 114926
20. LAZAROU M, SLITER DA, KANE LA, SARRAF SA, WANG C, BURMAN JL, SIDERIS DP, FOGEL AI, YOULE RJ 2015 The ubiquitin kinase PINK1 recruits autophagy receptors to induce mitophagy. Nature 524(7565): 309-314. https://doi.org/10.1038/nature14893

21. MEENA NP, ZHU G, MITTELSTADT PR, GIARDINO TORCHIA ML, POURCELOT M, ARNOULT D, ASHWELL JD, MUNITIC I 2016 The TBK1-binding domain of optineurin promotes type I interferon responses. FEBS Lett 590(10): 1498-1508. https://doi.org/10.1002/1873-3468.12176

22. NAKAZAWA S, OIKAWA D, ISHII R, AYAKI T, TAKAHASHI H, TAKEDA H, ISHITANI R, KAMEI K, TAKEYOSHI I, KAWAKAMI H, IWAI K, HATADA I, SAWASAKI T, ITO H, NUREKI O, TOKUNAGA F 2016 Linear ubiquitination is involved in the pathogenesis of optineurin-associated amyotrophic lateral sclerosis. Nat Commun 7: 12547. https://doi.org/10.1038/ ncomms12547

23. YING H, SHEN X, PARK B, YUE BY 2010 Posttranslational modifications, localization, and protein interactions of optineurin, the product of a glaucoma gene. PLoS One 5(2): e9168. https://doi. org/10.1371/journal.pone.0009168

24. GAO J, OHTSUBO M, HOTTA Y, MINOSHIMA S 2014 Oligomerization of optineurin and its oxidative stress- or E50K Mutationdriven covalent cross-linking: possible relationship with glaucoma pathology. PLoS One 9(7): e101206. https://doi.org/10.1371/journal.pone.0101206

25. OSAWA T, MIZUNO Y, FUJITA Y, TAKATAMA M, NAKAZATO Y, OKAMOTO K 2011 Optineurin in neurodegenerative diseases. Neuropathology 31(6): 569-574. https://doi.org/ 10.1111/j.1440-1789.2011.01199.x

26. YING H, YUE BY 2012 Cellular and molecular biology of optineurin. Int Rev Cell Mol Biol 294223-258. https://doi.org/10.1016/ B978-0-12-394305-7.00005-7

27. DEL TORO D, ALBERCH J, LAZARO-DIEGUEZF, MARTINIBANEZ R, XIFRO X, EGEA G, CANALS JM 2009 Mutant huntingtin impairs post-Golgi trafficking to lysosomes by delocalizing optineurin/Rab8 complex from the Golgi apparatus. Mol Biol Cell 20(5): 1478-1492. https://doi.org/10.1091/mbc.e08-07-0726

28. TURTURRO S, SHEN X, SHYAM R, YUE BY, YING H 2014 Effects of mutations and deletions in the human optineurin gene. Springerplus 3:99. https://doi.org/10.1186/2193-1801-3-99

29. SUNDARAMOORTHY V, WALKER AK, TAN V, FIFITA JA, MCCANN EP, WILLIAMS KL, BLAIR IP, GUILLEMIN GJ, FARG MA, ATKIN JD 2015 Defects in optineurin- and myosin VI-mediated cellular trafficking in amyotrophic lateral sclerosis. Hum Mol Genet 24(13): 3830-3846. https://doi.org/10.1093/hmg/ ddx 268

30. SHEN WC, LI HY, CHEN GC, CHERN Y, TU PH 2015 Mutations in the ubiquitin-binding domain of OPTN/optineurin interfere with autophagy-mediated degradation of misfolded proteins by a dominant-negative mechanism. Autophagy 11(4): 685-700. https://doi.org/10.4161/auto.36098

31. HARDIMAN O, AL-CHALABI A, CHIO A, CORR EM, LOGROSCINO G, ROBBERECHT W, SHAW PJ, SIMMONS Z, VAN DEN BERG LH 2017 Amyotrophic lateral sclerosis. Nat Rev Dis Primers 3:17071. https://doi.org/10.1038/nrdp.2017.71

32. BROWN RH, AL-CHALABI A 2017 Amyotrophic lateral sclerosis. N Engl J Med 377(2): 162-172. https://doi.org/10.1056/NEJMra1603471

33. MEJZINI R, FLYNN LL, PITOUT IL, FLETCHER S, WILTON SD, AKKARI PA 2019 ALS genetics, mechanisms, and therapeutics: Where are we now? Front Neurosci 13:1310. https://doi.org/ 10.3389/fnins.2019.01310

34. YERBURY JJ, OOI L, DILLIN A, SAUNDERS DN, HATTERS DM, BEART PM, CASHMAN NR, WILSON MR, ECROYD H 2016 Walking the tightrope: proteostasis and neurodegenerative disease. J Neurochem 137(4): 489-505. https://doi.org/10.1111/ jnc. 13575 
35. TAYLOR JP, BROWN RH, CLEVELAND DW 2016 Decoding ALS: from genes to mechanism. Nature 539(7628): 197-206. https://doi.org/10.1038/nature

36. CIRYAM P, LAMBERT-SMITH IA, BEAN DM, FREER R, CID F, TARTAGLIA GG, SAUNDERS DN, WILSON MR, OLIVER SG, MORIMOTO RI, DOBSON CM, VENDRUSCOLO M, FAVRIN G, YERBURY JJ 2017 Spinal motor neuron protein supersaturation patterns are associated with inclusion body formation in ALS. Proc Natl Acad Sci U S A 114(20): E3935-E3943. https:// doi.org/10.1073/pnas.1613854114

37. GLEASON CE, ORDUREAU A, GOURLAY R, ARTHUR JS, COHEN P 2011 Polyubiquitin binding to optineurin is required for optimal activation of TANK-binding kinase 1 and production of interferon $b$. J Biol Chem 286(41): 35663-35674. https://doi. org/10.1074/jbc.M111.267567

38. MUNITIC I, GIARDINO TORCHIA ML, MEENA NP, ZHU G, LI CC, ASHWELL JD 2013 Optineurin insufficiency impairs IRF3 but not NF- $\kappa$ B activation in immune cells. J Immunol 191(12): 6231-6240. https://doi.org/10.4049/jimmunol.1301696

39. SLOWICKA K, VEREECKE L, MC GUIRE C, SZE M, MAELFAIT J, KOLPE A, SAELENS X, BEYAERT R, VAN LOO G 2016 Optineurin deficiency in mice is associated with increased sensitivity to Salmonella but does not affect proinflammatory NF-kappaB signaling. Eur J Immunol 46(4): 971-980. https://doi.org/10.1002/ eji. 201545863

40. ITO Y, OFENGEIM D, NAJAFOV A, DAS S, SABERI S, LI Y, HITOMI J, ZHU H, CHEN H, MAYO L, GENG J, AMIN P, DEWITT JP, MOOKHTIAR AK, FLOREZ M, OUCHIDA AT, FAN J-B, PASPARAKIS M, KELLIHER MA, RAVITS J, YUAN J 2016 RIPK1 mediates axonal degeneration by promoting inflammation and necroptosis in ALS. Science 353(6299): 603-608. https://doi.org/10.1126/science.aaf6803

41. CHEW TS, O'SHEA NR, SEWELL GW, OEHLERS SH, MULVEY CM, CROSIER PS, GODOVAC-ZIMMERMANN J, BLOOM SL, SMITH AM, SEGAL AW 2015 Optineurin deficiency contributes to impaired cytokine secretion and neutrophil recruitment in bacteria driven colitis. Dis Model Mech 8(8): 817829. https://doi.org/10.1242/dmm.020362

42. DERMENTZAKI G, POLITI KA, LU L, MISHRA V, PÉREZTORRES EJ, SOSUNOV AA, MCKHANN GM, LOTTI F, SHNEIDER NA, PRZEDBORSKI S 2019 prevents motor neuron death in vitro but not in vivo. eNeuro 6(1): ENEURO.0308-18.2018. https://doi.org/10.1523/ENEURO.0308-18.2018

43. DUTTA S, SENGUPTA P 2016 Men and mice: Relating their ages. Life Sciences 152: 244-248. https://doi.org/10.1016/j.lfs.2015.10.025

44. PICHER-MARTEL V, VALDMANIS PN, GOULD PV, JULIEN JP, DUPRÉ N 2016 From animal models to human disease: a genetic approach for personalized medicine in ALS. Acta Neuropathol Commun 4(1): 70. https://doi.org/10.1186/s40478-016-0340-5

45. GURNEY ME, PU H, CHIU AY, DAL CANTO MC, POLCHOW CY, ALEXANDER DD, CALIENDO J, HENTATI A, KWON YW, DENG HX, ET A 1994 Motor neuron degeneration in mice that express a human $\mathrm{Cu}, \mathrm{Zn}$ superoxide dismutase mutation. Science 264(5166): 1772-1775. https://doi.org/10.1126/science. 8209258

46. PETROV D, MANSFIELD C, MOUSSY A, HERMINE O 2017 ALS Clinical trials review: 20 years of failure. are we any closer to registering a new treatment. Front Aging Neurosci 9:68. https://doi. org/10.3389/fnagi.2017.00068

47. FIFITA JA, WILLIAMS KL, SUNDARAMOORTHY V, MCCANN EP, NICHOLSON GA, ATKIN JD, BLAIR IP 2017 A novel amyotrophic lateral sclerosis mutation in OPTN induces ER stress and Golgi fragmentation in vitro. Amyotroph Lateral Scler Frontotemporal Degener 18(1-2): 126-133. https://doi.org/10.1080 /21678421.2016.1218517

48. MCGEER PL, MCGEER EG, KAWAMATA T, YAMADA T, AKIYAMA H 1991 Reactions of the immune system in chronic degenerative neurological diseases. Can J Neurol Sci 18(3 Suppl): 376-379. https://doi.org/10.1017/s0317167100032479

49. JULIEN JP 2007 ALS: astrocytes move in as deadly neighbors. Nat Neurosci 10(5): 535-537. https://doi.org/10.1038/nn0507-535

50. FREISCHMIDT A, WIELAND T, RICHTER B, RUF W, SCHAEFFER V, MULLER K, MARROQUIN N, NORDIN F, HUBERS A, WEYDT P, PINTO S, PRESS R, MILLECAMPS S, MOLKO N, BERNARD E, DESNUELLE C, SORIANI MH, DORST J, GRAF E, NORDSTROM U, FEILER MS, PUTZ S, BOECKERS TM, MEYER T, WINKLER AS, WINKELMAN J, DE CARVALHO M, THAL DR, OTTO M, BRANNSTROM T, VOLK AE, KURSULA P, DANZER KM, LICHTNER P, DIKIC I, MEITINGER T, LUDOLPH AC, STROM TM, ANDERSEN PM, WEISHAUPT JH 2015 Haploinsufficiency of TBK1 causes familial ALS and fronto-temporal dementia. Nat Neurosci 18(5): 631-636. https://doi.org/10.1038/nn.4000

51. CIRULLI ET, LASSEIGNE BN, PETROVSKI S, SAPP PC, DION PA, LEBLOND CS, COUTHOUIS J, LU YF, WANG Q, KRUEGER BJ, REN Z, KEEBLER J, HAN Y, LEVY SE, BOONE BE, WIMBISH JR, WAITE LL, JONES AL, CARULLI JP, DAYWILLIAMS AG, STAROPOLI JF, XIN WW, CHESI A, RAPHAEL AR, MCKENNA-YASEK D, CADY J, VIANNEY DE JONG JM, KENNA KP, SMITH BN, TOPP S, MILLER J, GKAZI A, AL-CHALABI A, VAN DEN BERG LH, VELDINK J, SILANI V, TICOZZI N, SHAW CE, BALOH RH, APPEL S, SIMPSON E, LAGIER-TOURENNE C, PULST SM, GIBSON S, TROJANOWSKI JQ, ELMAN L, MCCLUSKEY L, GROSSMAN M, SHNEIDER NA, CHUNG WK, RAVITS JM, GLASS JD, SIMS KB, VAN DEERLIN VM, MANIATIS T, HAYES SD, ORDUREAU A, SWARUP S, LANDERS J, BAAS F, ALLEN AS, BEDLACK RS, HARPER JW, GITLER AD, ROULEAU GA, BROWN R, HARMS MB, COOPER GM, HARRIS T, MYERS RM, GOLDSTEIN DB 2015 Exome sequencing in amyotrophic lateral sclerosis identifies risk genes and pathways. Science 347(6229): 1436-1441. https://doi.org/10.1126/science.aaa3650

52. MEDZHITOV R 2013 Pattern recognition theory and the launch of modern innate immunity. J Immunol 191(9): 4473-4474. https:// doi.org/10.4049/jimmunol.1302427

53. ZHU G, WU CJ, ZHAO Y, ASHWELL JD 2007 Optineurin negatively regulates TNFalpha- induced NF-kappaB activation by competing with NEMO for ubiquitinated RIP. Curr Biol 17(16): 1438-1443. https://doi.org/10.1016/j.cub.2007.07.041

54. AKIZUKI M, YAMASHITA H, UEMURA K, MARUYAMA H, KAWAKAMI H, ITO H, TAKAHASHI R 2013 Optineurin suppression causes neuronal cell death via NF- $\kappa$ B pathway. J Neurochem 126(6): 699-704. https://doi.org/10.1111/jnc.12326

55. SUDHAKAR C, NAGABHUSHANA A, JAIN N, SWARUP G 2009 NF-kappaB mediates tumor necrosis factor alpha-induced expression of optineurin, a negative regulator of NF-kappaB. PLoS One 4(4): e5114. https://doi.org/10.1371/journal.pone.0005114

56. LIU Z, LI H, HONG C, CHEN M, YUE T, CHEN C, WANG Z, YOU Q, LI C, WENG Q, XIE H, HU R 2018 ALS-associated E478G mutation in human OPTN (optineurin) promotes inflammation and induces neuronal cell death. Front Immunol 9:2647. https://doi.org/10.3389/fimmu.2018.02647

57. FITZGERALD KA, MCWHIRTER SM, FAIA KL, ROWE DC, LATZ E, GOLENBOCK DT, COYLE AJ, LIAO SM, MANIATIS T 2003 IKKepsilon and TBK1 are essential components of the IRF3 signaling pathway. Nat Immunol 4(5): 491-496. https://doi org/10.1038/ni921

58. BOXX GM, CHENG G 2016 The roles of type I interferon in bacterial infection. Cell Host Microbe 19(6): 760-769. https://doi org/10.1016/j.chom.2016.05.016

59. MANKOURI J, FRAGKOUDIS R, RICHARDS KH, WETHERILL LF, HARRIS M, KOHL A, ELLIOTT RM, MACDONALD A 2010 Optineurin negatively regulates the induction of IFNbeta in response to RNA virus infection. PLoS Pathog 6(2): e1000778. https://doi.org/10.1371/journal.ppat.1000778 
60. SILKE J, RICKARD JA, GERLIC M 2015 The diverse role of RIP kinases in necroptosis and inflammation. Nat Immunol 16(7): 689-697. https://doi.org/10.1038/ni.3206

61. MALIK BR, MADDISON DC, SMITH GA, PETERS OM 2019 Autophagic and endo-lysosomal dysfunction in neurodegenerative disease. Mol Brain 12(1): 100. https://doi.org/10.1186/s13041-0190504-x

62. OHSUMI Y 2014 Historical landmarks of autophagy research. Cell Res 24(1): 9-23. https://doi.org/10.1038/cr.2013.169

63. DOI H, ADACHI H, KATSUNO M, MINAMIYAMA M, MATSUMOTO S, KONDO N, MIYAZAKI Y, IIDA M, TOHNAI G, QIANG Q, TANAKA F, YANAGAWA T, WARABI E, ISHII T, SOBUE G 2013 p62/SQSTM1 differentially removes the toxic mutant androgen receptor via autophagy and inclusion formation in a spinal and bulbar muscular atrophy mouse model. J Neurosci 33(18): 7710-7727. https://doi.org/10.1523/JNEUROSCI.3021-12.2013

64. HADANO S, MITSUI S, PAN L, OTOMO A, KUBO M, SATO K, ONO S, ONODERA W, ABE K, CHEN X, KOIKE M, UCHIYAMA Y, AOKI M, WARABI E, YAMAMOTO M, ISHII T, YANAGAWA T, SHANG HF, YOSHII F 2016 Functional links between SQSTM1 and ALS2 in the pathogenesis of ALS: cumulative impact on the protection against mutant SOD1-mediated motor dysfunction in mice. Hum Mol Genet 25(15): 3321-3340. https:// doi.org/10.1523/jneurosci.3021-12.2013

65. MOORE AS, HOLZBAUR EL 2016 Dynamic recruitment and activation of ALS-associated TBK1 with its target optineurin are required for efficient mitophagy. Proc Natl Acad Sci U S A 113(24): E3349-58. https://doi.org/10.1073/pnas.1523810113

66. RICHTER B, SLITER DA, HERHAUS L, STOLZ A, WANG C, BELI P, ZAFFAGNINI G, WILD P, MARTENS S, WAGNER SA, YOULE RJ, DIKIC I 2016 Phosphorylation of OPTN by TBK1 enhances its binding to Ub chains and promotes selective autophagy of damaged mitochondria. Proc Natl Acad Sci U S A 113(15): 40394044. https://doi.org/10.1073/pnas.1523926113

67. FUJITA Y, OKAMOTO K 2005 Golgi apparatus of the motor neurons in patients with amyotrophic lateral sclerosis and in mice models of amyotrophic lateral sclerosis. Neuropathology 25(4): 388-394. https://doi.org/10.1111/j.1440-1789.2005.00616.x

68. TODD AG, LIN H, EBERT AD, LIU Y, ANDROPHY EJ 2013 COPI transport complexes bind to specific RNAs in neuronal cells. Hum Mol Genet 22(4): 729-736. https://doi.org/10.1093/hmg/ dds 480

69. XU X, KEDLAYA R, HIGUCHI H, IKEDA S, JUSTICE MJ, SETALURI V, IKEDA A 2010 Mutation in archain 1, a subunit of COPI coatomer complex, causes diluted coat color and Purkinje cell degeneration. PLoS Genet 6(5): e1000956. https://doi.org/10.1371/ journal.pgen.1000956

70. VAN DIS V, KUIJPERS M, HAASDIJK ED, TEULING E, OAKES SA, HOOGENRAAD CC, JAARSMA D 2014 Golgi fragmentation precedes neuromuscular denervation and is associated with endosome abnormalities in SOD1-ALS mouse motor neurons. Acta Neuropathol Commun 238. https://doi.org/10.1186/20515960-2-38

71. YAMANAKA T, NUKINA N 2018 ER dynamics and derangement in neurological diseases. Front Neurosci 1291. https://doi.org/ 10.3389/fnins.2018.00091

72. YANG YS, HAREL NY, STRITTMATTER SM 2009 Reticulon4A (Nogo-A) redistributes protein disulfide isomerase to protect mice from SOD1-dependent amyotrophic lateral sclerosis. J Neurosci 29(44): 13850-13859. https://doi.org/10.1523/jneurosci.2312-09.2009

73. SHEN X, YING H, QIU Y, PARK JS, SHYAM R, CHI ZL, IWATA T, YUE BY 2011 Processing of optineurin in neuronal cells. J Biol Chem 286(5): 3618-3629. https://doi.org/10.1074/jbc. M110.175810

74. SIROHI K, CHALASANI ML, SUDHAKAR C, KUMARI A, RADHA V, SWARUP G 2013 M98K-OPTN induces transferrin receptor degradation and RAB12-mediated autophagic death in retinal ganglion cells. Autophagy 9(4): 510-527. https://doi. org/10.4161/auto. 23458

75. CHALASANI ML, KUMARI A, RADHA V, SWARUP G 2014 E50K-OPTN-induced retinal cell death involves the Rab GTPaseactivating protein, TBC1D17 mediated block in autophagy. PLoS One 9(4): e95758. https://doi.org/10.1371/journal.pone.0095758

76. SHIM MS, TAKIHARA Y, KIM KY, IWATA T, YUE BY, INATANI M, WEINREB RN, PERKINS GA, JU WK 2016 Mitochondrial pathogenic mechanism and degradation in optineurin E50K mutation-mediated retinal ganglion cell degeneration. Sci Rep 6: 33830. https://doi.org/10.1038/srep33830

77. RYAN TA, TUMBARELLO DA 2018 Optineurin: a coordinator of membrane-associated cargo trafficking and autophagy. Front Immunol 91024. https://doi.org/10.3389/fimmu.2018.01024

78. STOLZ A, ERNST A, DIKIC I 2014 Cargo recognition and trafficking in selective autophagy. Nat Cell Biol 16(6): 495-501. https:// doi.org/10.1038/ncb2979

79. YANG Y, KLIONSKY DJ 2020 Autophagy and disease: unanswered questions. Cell Death \& Differentiation 27(3): 858-871. https://doi.org/10.1038/s41418-019-0480-9

80. MIZUSHIMA N, YAMAMOTO A, MATSUI M, YOSHIMORI T, OHSUMI Y 2004 In vivo analysis of autophagy in response to nutrient starvation using transgenic mice expressing a fluorescent autophagosome marker. Mol Biol Cell 15(3): 1101-1111. https://doi. org/10.1091/mbc.e03-09-0704

81. NIXON RA 2013 The role of autophagy in neurodegenerative disease. Nat Med 19(8): 983-997. https://doi.org/10.1038/nm.3232

82. EVANS CS, HOLZBAUR ELF 2019 Autophagy and mitophagy in ALS. Neurobiol Dis 12235-40. https://doi.org/10.1016/j. nbd.2018.07.005

83. BOLAND B, YU WH, CORTI O, MOLLEREAU B, HENRIQUES A, BEZARD E, PASTORES GM, RUBINSZTEIN DC, NIXON RA, DUCHEN MR, MALLUCCI GR, KROEMER G, LEVINE B, ESKELINEN E-L, MOCHEL F, SPEDDING M, LOUIS C, MARTIN OR, MILLAN MJ 2018 Promoting the clearance of neurotoxic proteins in neurodegenerative disorders of ageing. Nature Reviews Drug Discovery 17(9): 660-688. https://doi. org/10.1038/nrd.2018.109

84. HEO JM, ORDUREAU A, PAULO JA, RINEHART J, HARPER JW 2015 The PINK1-PARKIN mitochondrial ubiquitylation pathway drives a program of OPTN/NDP52 Recruitment and TBK1 activation to promote mitophagy. Mol Cell 60(1): 7-20. https://doi. org/10.1016/j.molcel.2015.08.016

85. TUMBARELLO DA, WAXSE BJ, ARDEN SD, BRIGHT NA, KENDRICK-JONES J, BUSS F 2012 Autophagy receptors link myosin VI to autophagosomes to mediate Tom1-dependent autophagosome maturation and fusion with the lysosome. Nat Cell Biol 14(10): 1024-1035. https://doi.org/https://doi.org/10.1038/ncb2589

86. WONG YC, HOLZBAUR EL 2014 Optineurin is an autophagy receptor for damaged mitochondria in Parkin-mediated mitophagy that is disrupted by an ALS-linked mutation. Proc Natl Acad Sci U S A 111(42): E4439-48. https://doi.org/https://doi.org/10.1073/ pnas. 1405752111

87. WISE JP, PRICE CG, AMARO JA, CANNON JR 2018 Autophagy disruptions associated with altered optineurin expression in extranigral regions in a rotenone model of Parkinson's disease. Front Neurosci 12:289. https://doi.org/10.3389/fnins.2018.00289

88. CHO MH, CHO K, KANG HJ, JEON EY, KIM HS, KWON HJ, KIM HM, KIM DH, YOON SY 2014 Autophagy in microglia degrades extracellular $b$-amyloid fibrils and regulates the NLRP3 inflammasome. Autophagy 10(10): 1761-1775. https://doi. org/10.4161/auto.29647

89. EVANS CS, HOLZBAUR ELF 2020 Degradation of engulfed mitochondria is rate-limiting in optineurin-mediated mitophagy in neurons. eLife 9: e50260. https://doi.org/10.7554/eLife.50260 